\title{
Cultivating 'cities in the wilderness': New York City's commercial pleasure gardens and the British American pursuit of rural urbanism
}

\author{
VAUGHN SCRIBNER* \\ University of Central Arkansas, Department of History, Irby 105E, Conway, AR \\ 72036, USA
}

\begin{abstract}
Privately owned, for-profit, seasonal, walled-off venues that boasted a variety of flora and fauna in addition to other services like stages, buildings, thespians, musicians, exhibits and victuals, New York City's Vauxhall and Ranelagh commercial pleasure gardens blossomed by the mid-eighteenth century. An in-depth analysis of these pleasure gardens not only contributes to how we understand colonists' endeavours to support a more complete leisure sector, but also reveals the nuanced nature of the 'rural vs. urban' or 'wilderness vs. civilization' dyads. Ultimately, urban colonists hoped to embrace the rural nature of their surroundings to make their 'cities in the wilderness' more accessible, healthy places.
\end{abstract}

On 3 June 1765, John Jones of New York City announced that his 'Ranelagh Garden' - a 300 by 750-foot commercial pleasure garden located on the periphery of New York City, only about one quarter of a mile from the centre of the city - would be open to 'the Publick in general' in three days. Jones surely realized that his garden's bucolic arrangement of geometric gravel paths, carefully spaced shrubs, thick hedges, shady trees and fragrant flowers (Figures 1 and 2) would have struck many colonists as a welcome escape from what they increasingly deemed the noisome, crowded and miasmic environment of New York City. So too would the opportunity to nibble breakfast among hovering bumblebees or to sip 'Tea and Coffee in the Afternoon...served in the genteelest manner, and at so modest a rate' in a building tucked among such a beautiful landscape

* The author would like to thank Robert Lewis, Joshua Nygren, the anonymous peer reviewers and the editorial staff at Urban History for their invaluable aid in the piece. He would also like to thank the University Research Council at the University of Central Arkansas for financial support. The title is a play on the title of C. Bridenbaugh, Cities in the Wilderness: The First Century of Urban Life in America, 1625-1742 (Oxford, 1938). 


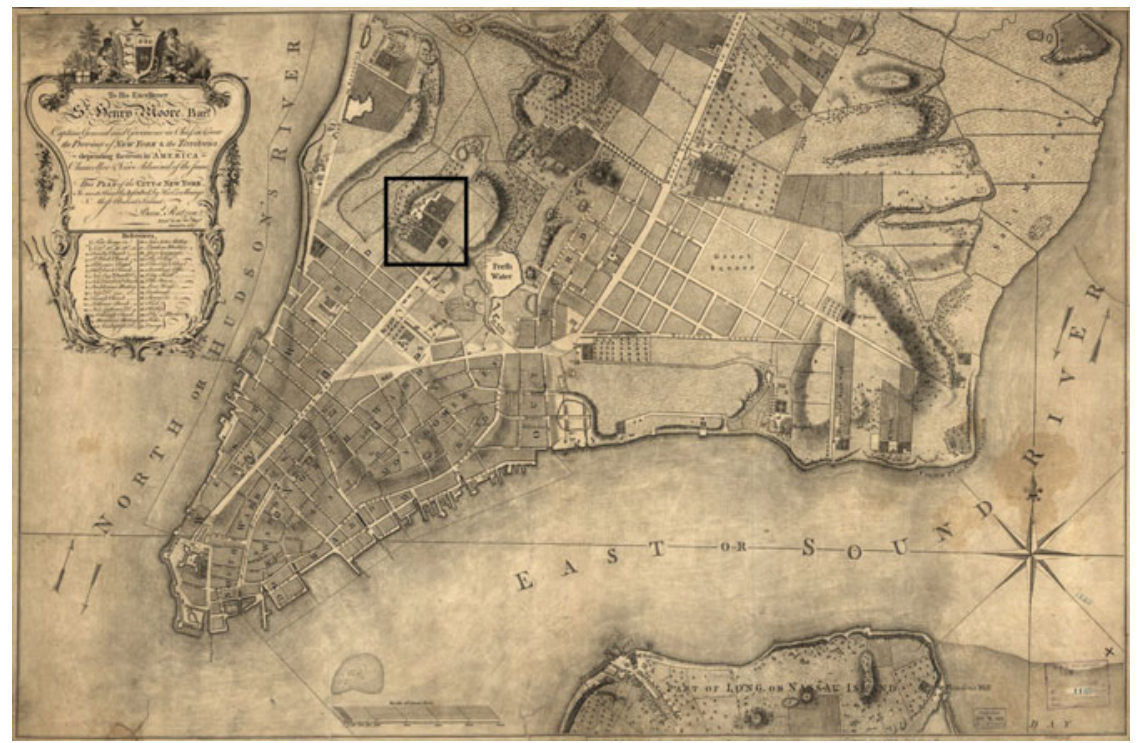

Figure 1: (Colour online) B. Ratzer and T. Kitchin, To His Excellency Sr. Henry Moore, Bart., Captain General and Governour in Chief, in $\mathcal{E}$ over the Province of New York $\mathcal{E}$ the Territories depending thereon in America, Chancellor $\mathcal{E}$ Vice Admiral of the Same. This Plan of the City of New York, Is Most Humbly Inscribed (London: Jefferys and Faden, 1776 [surveyed in 1767]), map, retrieved from the Library of Congress, www.loc.gov/item/74692118 (accessed 14 Jun. 2016).

attract urban dwellers. Determined 'to merit the applause' of his fellow New Yorkers, Jones took to the New-York Mercury to announce that, in addition to all the leisurely pleasures already available at Ranelagh, Jones would offer any customer who could pay the two shillings and three pence entrance fee a 'Concert of Musick' followed by a grand firework show. Jones' commercial pleasure garden was, in short, a venue that targeted colonists' desire for 'healthy' urban living. By shelling out a reasonable two shillings and three pence - for comparison, a bar of 'Superfine CrownSoap' sold in New York City for one shilling in 1767 - urbanites could temporarily escape the muck and bustle of New York City. And when they had their fill, they could easily return home, refreshed and ready to enjoy the opportunities of urban life. ${ }^{1}$

${ }^{1}$ New-York Mercury, 3 Jun. 1765; New-York Gazette, or Weekly Post-Boy, 15 Jan. 1767. For more on the city/country paradigm and how one might view the eighteenth-century city as intertwined with the natural world, see P. Borsay, 'Nature, the past and the English town: a counter-cultural history', Urban History, 44 (2017), 27-43; also see R. Williams, The City and the Country (Oxford, 1973). 


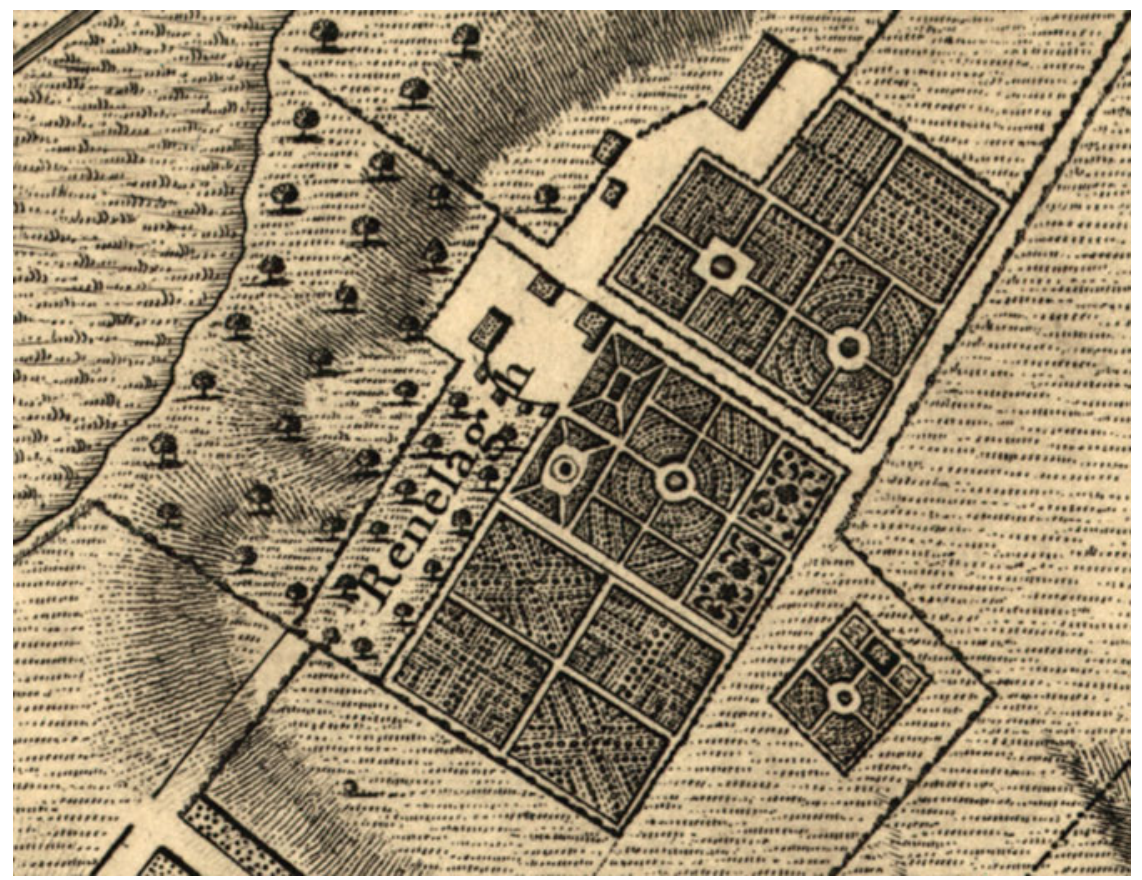

Figure 2: (Colour online) 'Detail of Ranelagh garden, 1767', in Ratzer and Kitchin, Plan of the City of New York, retrieved from the Library of Congress, www.loc.gov/item/74692118 (accessed 14 Jun. 2016).

Privately owned, for-profit, seasonal, walled-off venues that boasted a variety of flora and fauna in addition to other services like stages, buildings, thespians, musicians, exhibits and victuals, mid-century commercial pleasure gardens were open to any white person who could afford a ticket. Unlike the private pleasure gardens that wealthy colonists carefully cultivated on their own grounds, commercial pleasure gardens were public business operations intended to make a profit. $^{2}$ Though enterprising colonists in practically every burgeoning city attempted to cultivate commercial pleasure gardens, these bucolic spaces especially thrived in New York City. New York City's long-standing culture of public entertainment and diverse religious community were especially important

2 T.M. Garrett, 'A history of pleasure gardens in New York City, 1700-1865', New York University Ph.D. thesis, 1978, abstract. For more on the definition of the pleasure garden, see L. Douglas, 'Certain pleasures, ambiguous grounds: the etymology and evolution of the pleasure garden', Journal of Landscape Architecture, 8 (2013), 48-53, DOI: 10.1080/18626033.2013.798924; T. O'Malley, Keywords in Landscape Design (Washington, DC, 2010), 518-20. 
for its mid-century adoption of commercial pleasure gardens. ${ }^{3}$ While leaders in other major cities like Boston and Philadelphia levelled stringent religious and ideological opposition to such 'lewd' leisure spaces as 'spring gardens, bowling greens, and promenades', for instance, New York City's populace welcomed various leisure opportunities with open arms, thereby allowing businessmen to establish the 'Ranelagh' and 'Vauxhall' commercial pleasure gardens. ${ }^{4}$ Despite their growing reputation in the eyes of British American urban colonists, colonial American commercial pleasure gardens have received little historical attention, especially when compared to private pleasure gardens or public spaces like taverns, theatres, markets, shops and churches..$^{5}$ Those scholars who have studied American commercial pleasure gardens have generally concentrated on their pre-eminence in the federal era, relegating their colonial predecessors to the fringes of the historical record, while commercial pleasure gardens have been largely neglected in leading texts on the history of British American urban development. ${ }^{6}$ For mid-century colonists, however,

${ }^{3}$ In 1757, colonist William Smith Jr declared 'New-York is one of the most social Places on the Continent'. He continued to note 'The Inhabitants of New-York are a mixed People', listing 11 churches of varying denominations and religions. W. Smith Jr, The History of the Province of New-York: First Discovery to the Year 1732 (London, 1757), 211, 189, 194.

${ }^{4}$ E. Milroy, "'For the like uses as the moore-fields": the politics of Penn's Squares', Pennsylvania Magazine of History and Biography, 130 (2006), 277. For more on resistance to entertainment and leisure in Boston and Philadelphia, see Boston News-Letter, 10 Jul. 1750; D. McDermott, 'Structure and management in the American theatre from the beginning to 1870 ', in D. Wilmeth and C. Bigsby (eds.), The Cambridge History of American Theatre, vol. I: Beginnings to 1870 (Cambridge, 2006), 182-215; V. Scribner, 'Transatlantic actors: the intertwining stages of George Whitefield and Lewis Hallam Sr., 1739-1756', Journal of Social History, 50 (2016), 1-27; H.S. Nathans, Early American Theater from the Revolution to Thomas Jefferson: Into the Hands of the People (Cambridge, 2003), 13-30; E. Milroy, The Grid and the River: Philadelphia's Green Places, 1682-1876 (University Park, 2016), 21-3.

${ }^{5}$ For investigations of other public spaces, see P. Thompson, Rum Punch and Revolution: Taverngoing and Public Life in Eighteenth-Century Philadelphia (Philadelphia, 1999); R.L. Bushman, The Refinement of America: Persons, Houses, Cities (New York, 1992); F. Rudolph, The American College \& University: A History (Athens, GA, 1990); O. Johnson, Absence and Memory in Colonial American Theatre: Fiorelli's Plaster (New York, 2006); V. Scribner, "The happy effects of these waters": colonial American mineral spas and the British civilizing mission', Early American Studies: An Interdisciplinary Journal, 14 (2016), 409-49; E. Hart, 'From field to plate: the colonial livestock trade and the development of an American economic culture', William and Mary Quarterly, 73 (2016), 107-40.

${ }^{6}$ Garrett concentrated on these spaces, but only in the context of colonial New York City, while Naomi J. Stubbs surveyed American pleasure gardens through the lens of race, class, nature and nationalism, but almost wholly in the early federal era. Barbara Wells Sarudy, finally, investigated the emergence of colonial American pleasure gardens, but only in the Chesapeake region (and, once again, primarily in the federal era). Garrett, 'A history of pleasure gardens'; N.J. Stubbs, Cultivating National Identity through Performance: American Pleasure Gardens and Entertainment (New York, 2013); B.W. Sarudy, Gardens and Gardening in the Chesapeake, 1700-1805 (Baltimore, 1998), ch. 9. For those works which have concentrated on federal era pleasure gardens, see H.D. Eberlein and C. Hubbard, 'The American "Vauxhall" of the federal era', Pennsylvania Magazine of History and Biography, 57 (1944), 150-74; S.M. Vallillo and M. Chach (eds.), 'Pleasure gardens', special issue, Performing Arts Resources, 21 (1998); M. Henderson, The City and the Theatre: The History of New York Playhouses: A 250 Year Journey from Bowling Green to Times Square (New York, 2003); O'Malley, Keywords, 520; A. Beamish, 'Enjoyment in the night: discovering leisure in 
commercial pleasure gardens were hardly on the margins of urban society. An in-depth analysis of New York City's Vauxhall and Ranelagh commercial pleasure gardens not only contributes to how we understand colonists' endeavours to support a more complete leisure sector, but also reveals the nuanced nature of the 'rural vs. urban' or 'wilderness vs. civilization' dyads. Ultimately, urban colonists hoped to embrace the rural nature of their surroundings to make their 'cities in the wilderness' more accessible, healthy places.

This article analyses the evolution of the British American commercial pleasure garden - specifically New York City's popular Ranelagh and Vauxhall - to argue that colonists' desire for a dual urban-rural existence should be understood as a parallel rather than dichotomous aspect of their societal goals. Peter Borsay recently investigated such transformations in the context of the British city, contending that nature's role in city building only grew in importance 'as urbanization gathered pace' during the eighteenth century. The British American case offers a concurrent - yet also unique - vision of such efforts: in the process of emulating London's pleasure gardens, British American colonists channelled the inherently rustic nature of their surroundings to craft their own sort of commercial pleasure garden. While eighteenth-century Londoners struggled to conceive their green spaces 'as representative of nature' under the groaning weight of urban swell and over-population, furthermore, mid-century colonists were only just beginning to cultivate what might even be considered a small city in England. ${ }^{7}$ But one could not deny the staggering growth of British America: its total population increased by nearly 300 per cent between 1700 and 1750 and its largest cities expanded by an average of 170 per cent. As a more diverse set of colonists and travellers than ever crowded into the America's north-eastern cities, many looked for escapes from the enervating bustle of the city. New York City's Vauxhall and Ranelagh commercial pleasure gardens especially fulfilled

Philadelphia's eighteenth-century rural pleasure gardens', Studies in the History of Gardens \& Designed Landscapes: An International Quarterly, 35 (2015), 198-212. Carl Bridenbaugh never mentioned commercial pleasure gardens in his seminal Cities in Revolt (1955), nor did Gary Nash in The Urban Crucible (1979), or Richard Bushman in Refinement of America (1992), or Emma Hart in Building Charleston (2010), or Keith Krawczynski in Daily Life in the Colonial City (2013). C. Bridenbaugh, Cities in Revolt: Urban Life in America, 1743-1776 (New York, 1955), 143, 145, 339-40; G.B. Nash, The Urban Crucible: Social Change, Political Consciousness, and the Origins of the American Revolution (Cambridge, 1979); Bushman, The Refinement of America, 129-31; E. Hart, Building Charleston: Town and Society in the EighteenthCentury British Atlantic World (Charlottesville, 2010); K. Krawczynski, Daily Life in the Colonial City (Santa Barbara, 2013), 340. Benjamin Carp only mentioned New York City's Vauxhall Garden in the context of the Stamp Act riots in B.L. Carp, Rebels Rising: Cities and the American Revolution (Oxford, 2007), 82-3.

7 Borsay, 'Nature, the past and the English town', abstract, 5; R. Porter, London: A Social History (Cambridge, 1994), 98. 
that need, offering a wide range of people an accessible venue of rural leisure and global consumerism within the expanding nexus of the city. ${ }^{8}$

By the mid-eighteenth century, only 5 per cent of British North America's north-eastern inhabitants resided in cities. ${ }^{9}$ And while these colonial urban centres had made real strides in establishing themselves as anchors of Britain's globalizing empire, the colonies' most crowded cities still only equalled England's 'country towns' in total population and amenities. Philadelphia and New York City - the two largest cities in North America - harboured around 17,000 colonists in 1765, while London's population had ballooned to 750,000 souls. ${ }^{10}$ Public amenities like welllit streets, paved roads and brick buildings that would have seemed rather commonplace in a middle-sized English town, moreover, were only just beginning to mark these cities, as were leisure spheres such as coffeehouses, spas, bowling greens, theatres and promenades. ${ }^{11}$ Colonists knew that their cities ultimately relied upon their rural surroundings for trade, commerce, subsistence and further development, while visitors and locals alike sought out the supposed 'pastoral' nature - i.e. the romanticized 'rural and idyllic' landscape - of British America. Northeastern British America, in short, was still a far more rural than urban place, and its urbanization efforts greatly reflected such a realization. ${ }^{12}$

\section{A far green country}

Though colonists like Benjamin Franklin and Cadwallader Colden tirelessly strove to bolster British America's cosmopolitan identity, most

${ }^{8}$ For population increase, see R. Hofstadter, America at 1750: A Social Portrait (New York, 1973), 4. For more on the idea of hybridity in environmental history, see J. Clifford, 'The urban periphery and the rural fringe: West Ham's hybrid landscape', Left History, 13 (2008), 139; R. White, 'From wilderness to hybrid landscapes: the cultural turn in environmental history', in Douglas Cazaux Sackman (ed.), A Companion to American Environmental History (Malden, 2010), 188; P. Sutter, 'The world with us: the state of American environmental history', Journal of American History, 100 (2013), 96; S. Finger, The Contagious City: The Politics of Public Health in Early Philadelphia (Ithaca, 2012).

9 G.B. Nash, 'Social development', in J.P. Greene and J.R. Pole (eds.), Colonial British America: Essays in the New History of the Early Modern Era (Baltimore, 1984), 247.

${ }^{10}$ Nash, Urban Crucible, 409; Porter, London: A Social History, 98. Many colonists and visitors compared the mid-eighteenth-century colonies' cities to England's 'country towns'. C. Bridenbaugh (ed.), Gentleman's Progress: The Itinerarium of Dr. Alexander Hamilton, 1744 (Chapel Hill, 1948), 192-3; A. Burnaby, Travels through the Middle Settlements in North America in the Years 1759 and 1760 (Dublin, 1775), 169.

11 As O.T. Barck noted, New York City and its environs remained 'a rural rather than urban area' by 1763. O.T. Barck, New York City during the War for Independence: With Special Reference to the Period of British Occupation (New York, 1931), 12.

12 'pastoral, n. and adj', OED online, Sep. 2016, Oxford University Press, www.oed.com.ezpprod1.hul.harvard.edu/view/Entry/138625? rskey=NygElh\&result=1\&isAdvanced= false (accessed 5 Oct. 2016). For a further discussion of ideas of pastoralism in early America, see T. Hallock, From the Fallen Tree: Frontier Narratives, Environmental Politics, and the Roots of a National Pastoral, 1749-1826 (Chapel Hill, 2003). For more on colonists' 'romantic' notions of 'wilderness', see R.F. Nash, Wilderness and the American Mind, 4th edn (New Haven, 2001), 44-66. 
of the western world still recognized the colonies for their agricultural potential and vast 'wilderness'. Colonists' primary importance for the British empire, after all, rested on their ability to produce raw goods far more than their propensity for city building. Inhabitants and outsiders consequently approached the colonies with a diverse - and equally subjective - cache of ideologies, specifically notions of 'wilderness', 'civilization', 'nature' and 'health'. In classical thought, 'wilderness' was the base opposite of 'civilization' - according to Englishman Samuel Johnson's seminal Dictionary (1755), wilderness was 'a tract of solitude and savageness', while civilization was, quite simply, 'not wild'. To 'civilize', in Johnson's contention, was to 'reclaim from savageness and brutality; to instruct in the arts of regular life ${ }^{\prime 13}$ For British American colonists, however, the supposed dichotomy between wilderness and savagery blurred by the day. No matter how much colonists asserted their civil cosmopolitanism, they remained surrounded by what they considered 'savage' Native Americans and a 'wild' backcountry. As historian Richard Bushman recently asserted, 'a shade of rusticity tinged American life. In the eyes of Europe, the wilderness overhung the most advanced American cities.' But this was not necessarily a bad thing - it is no coincidence that Benjamin Franklin, perhaps the most urbane and cosmopolitan of all British American colonists, donned a coonskin cap while visiting the French court in the late 1770s. For a growing number of mid-century British American colonists, that very 'shade of rusticity' is what might make their cities more healthy and desirable places to live. ${ }^{14}$

Early modern Britons attempted to place 'nature' and 'health' within their increasingly muddled notions of wilderness and civilization. As two of the most complicated - yet also connected - concepts in the English mindset, 'nature' might benefit as easily as harm one's 'health', as human health was considered wholly connected to the natural world in which one's body resided. Europeans believed that travelling to a new climate might have real effects on their bodily and mental health, as in their minds the natural world and climate in a new place could alter the very composition of their bodies. Yet they also believed that, if 'improved' through proper methods of construction, order and urbanization, the wild aspects of the natural world might also be utilized for healthful purposes. ${ }^{15}$

${ }^{13}$ S. Johnson, Dictionary of the English Language, 2 vols. (London, 1785), vol. II, 1062, vol. I, 386. For a further discussion of how early modern Britons viewed 'nature' and 'wilderness', see Nash, Wilderness and the American Mind, 1-66.

14 R. Bushman, 'American high-style and vernacular cultures', in Greene and Pole (eds.), Colonial British America, 369; Z. Anishanslin, Portrait of a Woman in Silk: Hidden Histories of the British Atlantic World (New Haven, 2016), 16-17.

${ }^{15}$ For more on early modern Britons' complicated conceptions of 'health' and 'nature', see M. Dennis, 'Cultures of nature: to ca. 1810', in Sackman (ed.), A Companion to American Environmental History, 214-45; K.O. Kupperman, 'Fear of hot climates in the angloAmerican colonial experience', William and Mary Quarterly, 41 (1984), 213-14; R. Porter, Enlightenment: Britain and the Creation of the Modern World (New York, 2000), especially ch. 
Visitors and residents alike repeatedly displayed such notions, describing the north-eastern seaboard of British North America in terms of its natural wilderness, health and inherent agricultural potential. While travelling through the New York backcountry in the 1750s, for instance, Massachusetts Governor Thomas Pownall could only exclaim, 'with what an overflowing Joy does the Heart melt, while one views the Banks where rising Farms, new Fields, or flowering Orchards begin to illuminate his Face of Nature; nothing can be more delightful to the Eye, nothing go with more penetrating Sensation to the Heart'. ${ }^{16}$ Upon touring Pennsylvania, similarly, Englishwoman Susannah Wright expounded upon the colony's natural attractions, remarking that Pennsylvania "Tis certainly the pleasantest Country as can be always Clear Weather \& a wholesome air.' The woods, she continued, were filled with an 'abundance of sweet shrubs \& charming trees with abundance of birds singing ${ }^{\prime}{ }^{17}$ Despite lingering fears of the wilderness, mid-century settlers increasingly viewed America's uncultivated lands such as the Ohio country as brimming with potential: 'want[ing] nothing but Cultivation to make it a most delightful Country'. By the close of the eighteenth century, one Swiss visitor to the Ohio Country could only assert that the region 'may...be affirmed to be the most healthy, the most pleasant, the most commodious and most fertile spot of earth, known to the European people'. In the minds of most Britons, North America was primarily a bucolic country, offering the possibility of subjective notions like wilderness and health in equal portions. Recognizing this opportunity, colonial leaders attempted to harness the healthy aspects of the natural world while resisting its inherently dangerous features. ${ }^{18}$

British American cities had long harboured a distinct pastoral identity. Green spaces and features such as trees, orchards, open fields, squares, ornamental flowers, clipped shrubs and suburban mansions remained central concerns for urbanites as they attempted to develop their cities into urban reflections of British American prosperity and order. William Penn, perhaps the most famous of all city builders in North America, developed Philadelphia according to his love of the English country estate more than a desire to equal Europe's metropolises. His original plans for a 'greene Country Towne' called for each individual home to boast a sizeable (private) green area, in addition to the city harbouring various other green

13: 'Nature'; Nash, Wilderness and the American Mind, 1-66; Scribner, "'Happy effects of these waters"'.

${ }^{16}$ T. Pownall, 'A memorial stating the nature of the service in North America, and proposing a general plan of operations, as founded thereon' [1756], repr. in T. Pownall, The Administration of the British Colonies. The Fifth Edition. Wherein their Rights and Constitution Are Discussed and Stated, 5th edn, 2 vols. (1764; London, 1774), vol. II, 183-4.

17 M. Kraus, 'America and the utopian ideal in the eighteenth century', in P.C. Hoffer (ed.), An American Enlightenment: Selected Articles on Colonial Intellectual History (New York, 1988), 3 (quote).

18 C. Gist, Christopher Gist's Journals, ed. W.M. Darlington (Pittsburgh, 1893), 47; J. Walker, Elements of Geography and of Natural and Civil History (London, 1795), 593. 
spaces and wide boulevards. Penn ultimately plotted his 'Well-Organized and Healthy Town' to mirror English formal gardens, planning for his city to boast five interconnected squares within a quadripartite grid of streets. Yet Penn did not foresee his city as a hive of pleasure gardens ever the Quaker pragmatist, Penn contended that his tree-filled 'squares' should be devoted to the 'best recreation' such as religious assemblies and husbandry rather than the incivility that London's green spaces supposedly encouraged. ${ }^{19}$ Though New York City's development was not as well planned as Philadelphia's - streets and lots were approved on an ad hoc basis by the Corporation - locals were nevertheless very concerned with retaining a pastoral identity. One New Yorker, for instance, took to his local newspaper to 'applaud the Corporation for the many new and useful improvements and regulations they have made, and are continually making, whereby the city becomes daily more clean, wholesome, and beautiful' ${ }^{20}$ Such organizational concerns were based upon health as much as aesthetics and civility, as colonial gentlemen understood their new cities as opportunities to craft healthy, ordered alternatives to the relative crowding, disorder and disease that characterized Old World urban centres. ${ }^{21}$

What emerged by the mid-eighteenth century were colonial cities that would have seemed much less congested - and greener - than many of their European counterparts, especially during the summer and spring months. Most of Philadelphia that Penn had previously laid out remained heavily forested and largely undeveloped until after the 1770s when the proprietary lost control of the land. New York City's buildings, meanwhile, remained huddled at the tip of Manhattan Island, punctuated by groves of trees, a fresh-water pond and various pastures, gardens and other

${ }^{19}$ Milroy, Grid and the River, 21 (quote), 11-49; Milroy, 'The politics of Penn's squares', 276-8; J.W. Reps, The Making of Urban America: A History of City Planning in the United States (Princeton, 1965), 147-74. As historian Elizabeth Milroy noted, '[Penn] specifically instructed his commissioners to find a site that was "high, dry, and healthy", and in subsequent promotional writings he emphasized the fact that Philadelphia's site was noted for "the loftiness and soundness of the Land and the Air"'. Milroy, 'The politics of Penn's squares', 274-5. Milroy also explained that 'William Penn's presence in the colony may have prompted the formulation of an ordinance passed in 1700 that required all those residing in houses in Philadelphia...to plant trees in front of their houses'. Milroy, Grid and the River, 29.

${ }^{20}$ New-York Journal, 16 Jun. 1774.

${ }^{21}$ Southern gentlemen also crafted their cities according to the most up-to-date city-building methods. J.D. Kornwolf, Architecture and Town Planning in Colonial North America, vol. III (Baltimore, 2002), 1251; P. Martin, The Pleasure Gardens of Virginia: From Jamestown to Jefferson (Charlottesville, 2001), 28, 30-1;J.W. Reps, Tidewater Towns: City Planning in Colonial Virginia and Maryland (Williamsburg, 1972); Sarudy, Gardens and Gardening, 128-33. Hugh Jones, for example, equated Williamsburg's order and verdant nature with health, exclaiming that residents of Williamsburg 'dwell comfortably, genteely, pleasantly, and plentifully in this delightful, healthful, and (I hope) thriving city of Williamsburgh': H. Jones, The Present State of Virginia (New York, 1865 (orig. printed in 1724)), 32; T. Wilson, The Oglethorpe Plan: Enlightenment Design in Savannah and Beyond (Charlottesville, 2012), Introduction. 
green spaces. ${ }^{22}$ Visitors took notice. Upon touring the colonies in 1775 , the Scottish gentleman Patrick M'Robert exclaimed that Philadelphia's streets were 'in many parts agreeably shaded with trees in the summer; under whose shade the inhabitants sit and do business or regale themselves'. The visiting Scot also found that 'the country round [Philadelphia] is very pleasant and agreeable, finely interspersed with genteel country seats, fields and orchards'. After visiting New York, M'Robert described 'the woods, country houses, orchards, and fields of Indian corn [surrounding New York City]' as forming 'a beautiful prospect', and, upon entering the heart of New York City, remarked, 'the situation is extremly pleasant, upon a rising ground from the shore or river on both sides. The city is large, and contains a great many neat buildings. ${ }^{23}$ Three years later, a Hessian soldier stationed in New York City could only remark that Americans 'lived in the lap of the most beneficent Nature before the outbreak of these unhappy disturbances' ${ }^{24}$ Though visitors and citizens alike noted that British America's most populated cities retained clear physical, topographical and political differences, they also remarked upon at least one over-arching similarity: colonial cities remained considerably enmeshed in their rural surroundings. ${ }^{25}$

\section{The context for British American commercial pleasure gardens}

Besides existing in a New World environment often associated with pastoral plenty, the mid-century emergence of commercial pleasure gardens like New York City's Vauxhall and Ranelagh Gardens must be understood within the context of pre-existing urban spaces: specifically nurseries that dispersed seeds, fruits, vegetables and plants to local citizens; private pleasure gardens intended for exclusive leisure and/or self-subsistence; and public commons where urbanites could socialize or, increasingly, get into trouble. Taken together, these three urban spaces reveal colonists' evolving ideas of how their cities might harness the urban

22 Milroy, 'The politics of Penn's squares', 281-2; W. Dunlap, A History of the American Theatre (New York, 1832), 43; J.W. Reps, Town Planning in Frontier America (Princeton, 1969), 194-5. For notations of the mass amounts of trees in New York City, see P. Waldeck, Eighteenth Century America: A Hessian Report on the People, the Land, the War, As Noted in the Diary of Chaplain Philipp Waldeck (1776-1780), trans. B.E. Burgoyne (Bowie, MD, 1995), 18. The German Waldeck noted in Oct. 1776: 'The streets are rather wide, especially the so-called Broadway, where the King's statue stood. High trees stand before the houses.'

23 P. M'Robert, A Tour through Part of the North Provinces of America: Being, A Series of Letters Wrote on the Spot, in the Years 1774, \& 1775. To Which Are Annex'd, Tables, Shewing the Roads, the Value of Coins, Rates of Stages, Ec. (Pennsylvania, 1935), 30, 32, 2-3.

24 'Chapter XXI: from an officer in New York, 11 Sep. 1780', in R.W. Pettengill (trans.), Letters from America, 1776-1779, Being Letters of Brunswick, Hessian, and Waldeck Officers with the British Armies during the Revolution (Port Washington, 1964), 229; see also J.C. Döhla, A Hessian Diary of the American Revolution, ed. B.E. Burgoyne (Norman, 1990), 23-9.

${ }^{25}$ For more on the idea that historians should view urbanization in the northern and southern colonies as intertwined, see V. Scribner, "'Quite a genteel and extreamly commodious house": southern taverns, anxious elites, and the British American quest for social differentiation', Journal of Early American History, 5 (2015), 30-67. 
and rural impetuses of British America. These green spaces proved the genesis of the British American commercial pleasure garden.

As private businesses, gardens thrived. ${ }^{26}$ New York City gardener William Pride, for instance, maintained a successful nursery at midcentury from which he distributed a vast variety of seeds and produce across great distances. Situated 'about a Mile from the City of NewYork...in the Bowery-Lane', and 'containing near 12 acres of land' (see Figures 3 and 4), Pride's nursery was lauded for its 'choice Collection of the best Fruit of all Kinds, and... a large Nursery of young trees'. ${ }^{27}$ Besides local customers, ship captains bound for the West Indies were especially keen to purchase Pride's valuable stock. Before heading to St Croix in 1762, one captain requested a variety of seeds - ranging from red cabbage to turnips to radish to celery - in addition to 'Pease, of two or three of the best sort half a Gall. of each'. West Indian plantation owners would have greatly relied on such stock for their subsistence, as practically none of their Old World plants existed in their new surroundings. Local customers also flocked to Pride's nursery. In 1762, one citizen purchased '550 Plants and Seeds of Sorts' for his own private garden, while in 1764, the New York City lawyer, John Tabor Kempe, had Pride inoculate over 600 of his fruit-bearing trees. Though only a small sample of over 100 business transactions that Pride left behind, these instances provide the historian a keen example to glimpse into how urbanites retained real connections to the natural world. Nursery owners like Pride prospered in every major city in America by mid-century. ${ }^{28}$

Colonists usually cultivated their own private gardens 'for Use or for Delight'; i.e. for self-subsistence or genteel leisure. Wealthy men who liked to assert a 'genteel' identity were especially keen on turning their country houses into self-sufficient 'kingdoms' where they held ultimate sway over their surroundings, whether flora, fauna or human. Certain facets of these 'gentlemen's' gardens reflected such notions, as they were devoted primarily to producing crops intended for sustenance or medicine and were farmed by unfree or servile labourers. Other plantation gardens, meanwhile, were styled after English country homes' gardens, with gravel walkways, open landscapes and beautiful tertiaries intended primarily for aesthetic purposes. ${ }^{29}$

26 For more on nurseries in the colonies, see Sarudy, Gardens and Gardening, 3-19, 65-77; A. Leighton, American Gardens in the Eighteenth Century: 'For Use or for Delight' (Boston, 1986).

27 New-York Mercury, 7 Jul. 1766.

28 'Memorandum for Capt. Troy from James des Vories, St. Croix, 1 May 1762', 'New York Oct 22d 1762', 'An account of trees Enockelated for Mr Kempe, 1764', in John Tabor Kempe Papers, New York Historical Society, box 12, folder 3; Pride was not alone in serving West Indian captains. See, for instance, Boston News-Letter, 10 Mar. 1768: a local nursery owner advertised 'A Great variety of Garden Seeds, Fruit Trees of all kinds, suitable for this Country: as also, SEEDS saved here suitable for the West Indies; in said Seeds imported are eight different sorts of Peas.'

${ }^{29}$ Leighton, American Gardens, 248; R. Isaac, Landon Carter's Uneasy Kingdom: Revolution and Rebellion on a Virginia Plantation (Oxford, 2004). 


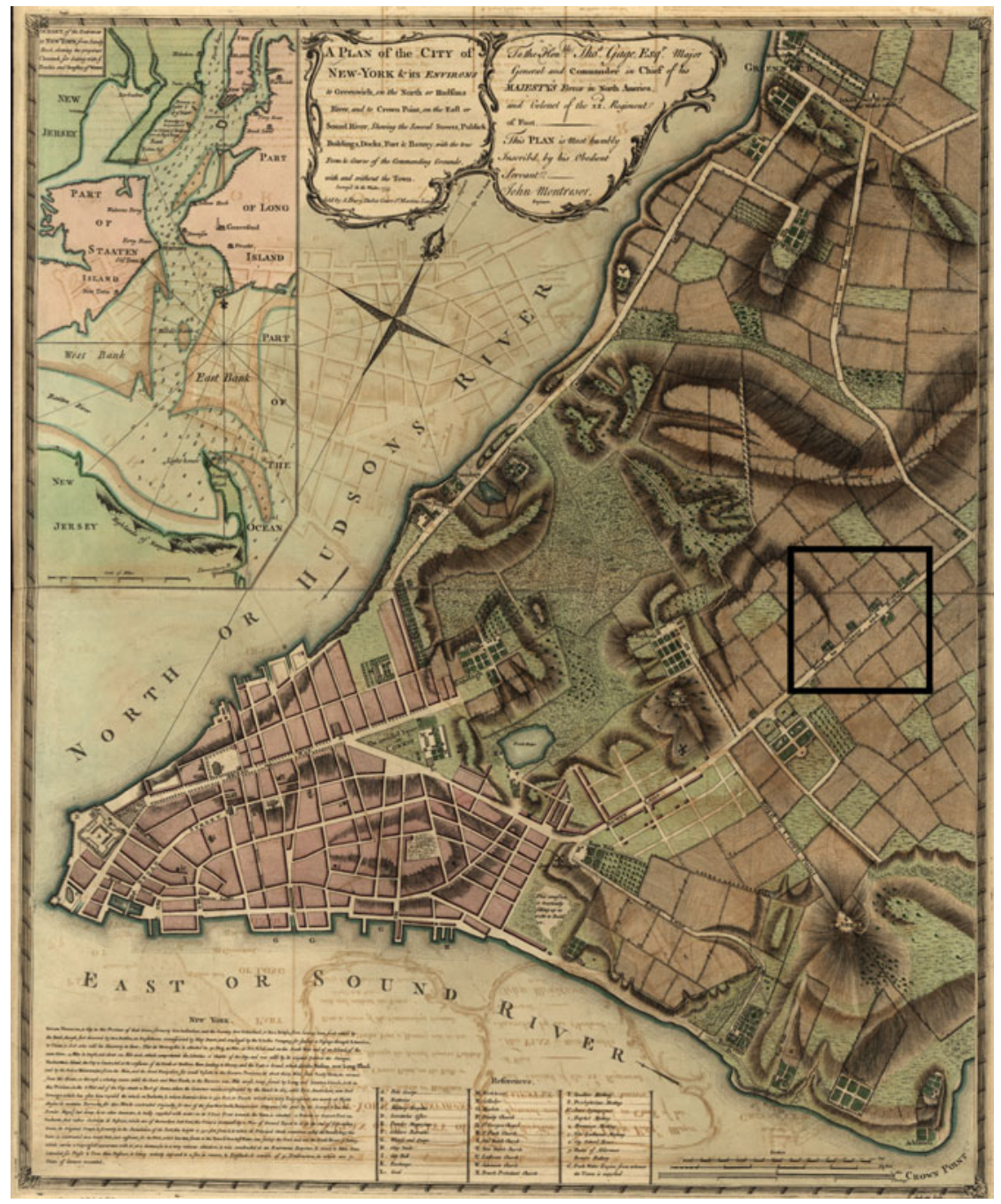

Figure 3: (Colour online) J. Montrésor, A Plan of the City of New-York $\mathcal{E}$ its Environs... (London, 1775), map, retrieved from the Library of Congress, www.loc.gov/item/74692879/ (accessed 31 Dec. 2016).

Ultimately, such gardens asserted a gentleman's civility and taste, two very important characteristics for a self-conscious elite. Though scholars have often considered urban gardening as almost wholly functional in contrast to more aesthetically determined country gardens, historian Peter Martin recently demonstrated that by the eighteenth century colonial urbanites were crafting their gardens into spaces that would have 


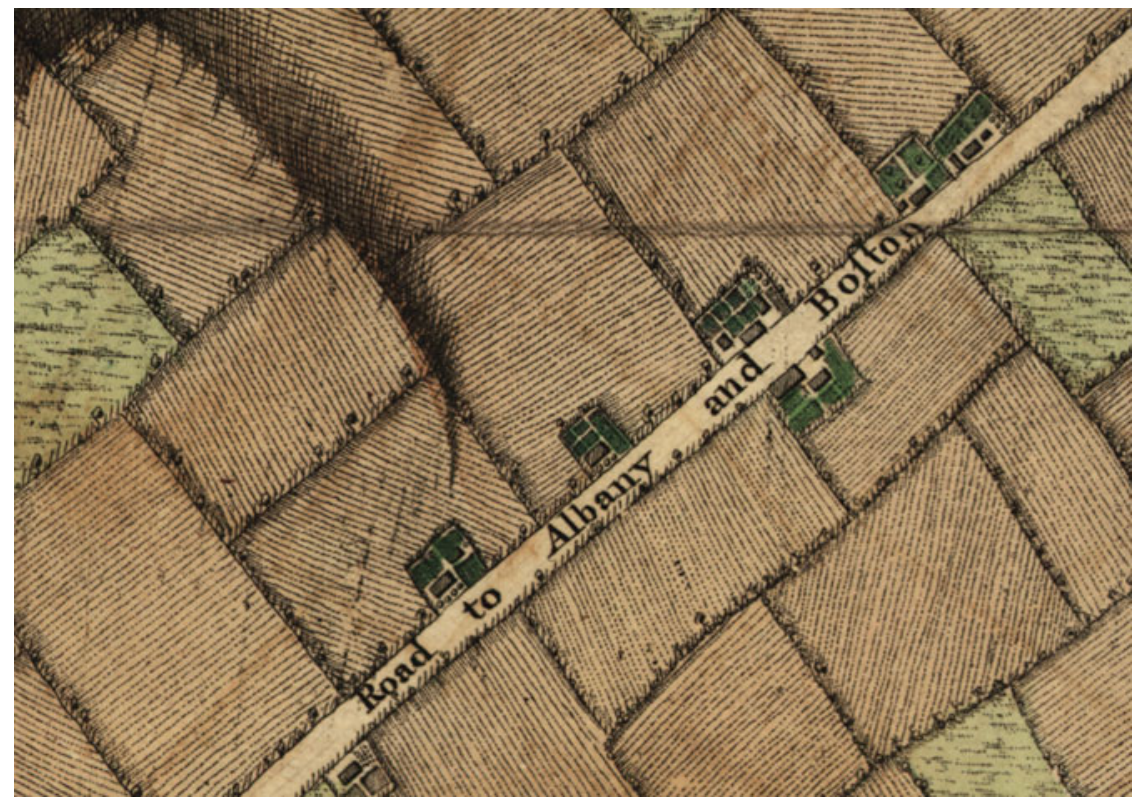

Figure 4: (Colour online) Detail from Montrésor, A Plan of the City of New-York $\mathcal{E}$ its Environs..., map, retrieved from the Library of Congress, www.loc.gov/item/74692879/ (accessed 31 Dec. 2016). Though I am not positive which of these plots was Pride's, records point to one of the above six plots - about a mile from town on Bowery Lane - as belonging to Pride. He died the year this map was created (1766), so his garden would have been featured on it.

resembled more picturesque gardens so often associated with plantation gardens (which were, in turn, copies of English country homes). Besides exchanging plants regularly with their compatriots in England, urban and rural dwelling gentlemen were also able to maintain gardens that would have been beautiful to the eye as well as somewhat productive. Thus, while two types of gardens - primarily sustenance-based or pictorial existed in the mid-century colonies, the two were not necessarily mutually exclusive. Colonial gentlemen, rather, fashioned gardens full of both native and imported plants according to prevailing English notions of open landscaping while also upholding private spaces where their friends would have happily congregated for leisure rather than labour. ${ }^{30}$

Public commons had long served urbanites as green spaces where all could congregate for a diverse set of purposes. Colonial American commons are perhaps just as difficult to define for the modern scholar as they were for colonial contemporaries. One might lump urban greens,

${ }^{30}$ Martin, Pleasure Gardens of Virginia, 55, 65. 
fields or squares under the umbrella of the common, but such a definition still would not hold true in every colony. Ultimately, a specific definition of the urban 'common' is not as important for this article's purposes as is the idea of the common, which remained firmly tethered to colonists' attempts at making their cities more communal and green places. Public commons were central in literal and figurative terms: not only were they often bordered by key public institutions like churches, taverns and meetinghouses, but commons were also open to all for a variety of purposes. Depending upon the day and time of year, a visitor to one of these commons might witness a military regiment parading through the green, livestock grazing, a burial (or hanging) taking place, an ad hoc public market, a blistering public speech (or, eventually, an open air sermon) or a group of boys frolicking in sport. ${ }^{31}$

As urban populations boomed at mid-century, however, commons increasingly became overcrowded spaces defined (at least in the eyes of leaders) by the impulses of uncivil society. Upon arriving in New York City in 1758, Philadelphian Hannah Callender noted that the city's fields/commons were marked by a 'Work-house (but it is for lunatics also), and a neat building just finished for a jail'. Seven years earlier, a citizen complained that 'roystering young men, full of tricks and mischief...gambol[ed] in [New York City's] fields'. Philadelphians, meanwhile, complained that their Centre Square commons had become a hive of 'pleasure, luxury, gaming, and dissipation'. By the second half of the eighteenth century, urbanites realized that they could not look to their commons for an escape from the tumult of the city. These spaces, on the contrary, had become concentrations of such impulses. ${ }^{32}$

The mass influence of elite cultural trends - specifically wealthy colonists' desire for a lifestyle that combined the convenience of the city and the perceived leisure of the countryside - were also key stimuli for the emergence of the British American commercial pleasure garden. When Robert Hardie advertised the sale of a 'commodious Brick House' in Philadelphia in 1764, he was sure to reference the 'fine garden to the House, very fit for a Gentleman's Seat, having a fine Prospect of the Country on one Side of the House, and a fine View of the City on the other'. ${ }^{33}$ By

${ }^{31}$ While cities like Philadelphia relied upon a grid-like plan which encompassed myriad smaller squares intended for the leisure of between four and eight bordering households, many other colonial urban centres - notably New York City and Boston - grew around larger, more shared public commons. For more on the many uses - and definitions - of the public common, see O'Malley, Keywords, 202-4.

32 H. Callender, 'Extracts from the diary of Hannah Callender', Pennsylvania Magazine of History and Biography, 12 (1888), 446; McDermott, 'Structure and management in the American theatre from the beginning to 1870', 185; E. Milroy, Grid and the River, 36; S. Barber, Boston Common: A Diary of Notable Events, Incidents, and Neighboring Occurrences, 2nd edn (Boston, 1916), 47, 63, 72.

33 Pennsylvania Gazette, 26 Apr. 1764. For more on the elite desire for a balance between country and city life, see M. Reinberger and E. McLean, The Philadelphia Country House: Architecture and Landscape in Colonial America (Baltimore, 2015), 44. 
mid-century, however, a booming population who had more expendable funds than ever before necessitated a more diverse leisure sphere in British America's cities. Those masses of urban dwellers who could not afford their own 'Gentleman's seat' still craved spaces where they too could have 'a fine Prospect of the Country.... and a fine View of the City'. Whether rich or poor, urban colonists demanded public places where they could not only 'see and be seen', but also where they might benefit from the 'greening of the urban landscape'. ${ }^{34}$

\section{London origins, colonial interpretations}

As demand for urban leisure spaces exploded at mid-century, nurseries, private gardens and commons no longer satiated many rich and poor urbanites' urban rural imaginations. Whether intended for business, selfsubsistence, leisure or a mixture of all three, commercial and private gardens remained exclusive spaces in the mid-century colonies: not just anyone could visit a gentleman's carefully manicured garden, and nurseries like Pride's were intended only for those with the means to purchase his products. While commons might have eventually evolved into commercial pleasure gardens, furthermore, they had become spaces defined by the lower classes and thus somewhat repugnant to condescending elites. Across the Atlantic Ocean, however, Englishmen had cultivated a different sort of garden over the last hundred years which would satisfy colonists' sociable tendencies while also maintaining the 'strengthened...balance between urban and plantation gardening' that colonists had worked hard to realize. Londoners invented this new public leisure space, and they called it the commercial pleasure garden. ${ }^{35}$

Chief among London's commercial pleasure gardens were Vauxhall and Ranelagh. Located on the south bank of the Thames River (see Figure 5), Vauxhall opened its gates in summer 1660. Whether arriving on foot or by a romantic boat ride, Vauxhall offered a diverse set of patrons a staggering array of entertainment and leisure opportunities: orchestras, fireworks, dancing, food, drink, art - all for only one shilling. Crowds in the thousands consisting of prostitutes, apprentices and aristocrats packed into the garden's sprawling acres, surveying rooms painted by the popular London artist William Hogarth, staring up at Roubiliac's statue of Handel, promenading through beautiful grottos, alcoves and squares, and, often, using these same nooks for more carnal purposes. The proprietors of

${ }^{34}$ Hofstadter, America at 1750, 158; Borsay, 'Nature, the past, and the English town', 6.

$35 \mathrm{H}$. Greig, "'All together and all distinct": public sociability and social exclusivity in London's pleasure gardens, ca. 1740-1800', Journal of British Studies, 51 (2012), 64; Martin, Pleasure Gardens of Virginia, 55. Because Englishmen - specifically Londoners - originally created the commercial pleasure garden, this article will concentrate on how Britons abroad - specifically British American colonists living on the north-eastern seaboard of mainland North America - sought to translate this English invention to North America's shores. 


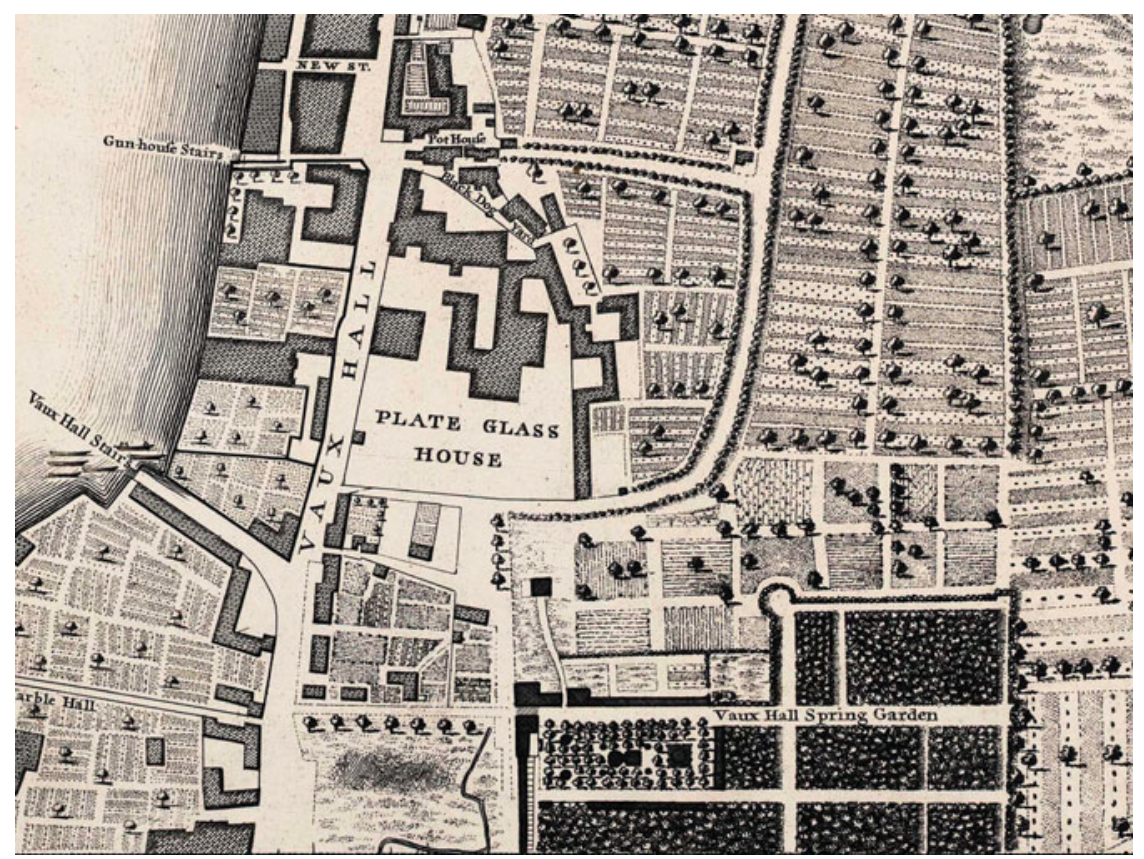

Figure 5: (Colour online) 'Vauxhall Pleasure Garden, London', detail from 'A plan of the cities of London and Westminster, and borough of Southwark', surveyed by J. Rocque and engraved by J. Pine (London, 1746), in J. Howgego (ed.), Printed Maps of London, c. 1533-1850, 2nd edn (Folkestone, 1978), no. 96, used with permission of Motco.

the Ranelagh Garden built off Vauxhall's popularity when they opened their fine venue next to Chelsea Hospital in 1742. Tobias Smollett likened Ranelagh to 'the enchanted palace of a genie' in his eighteenth-century novel, Humphry Clinker. 'Adorned with the most exquisite performance of painting, carving, and gilding, enlightened with a thousand golden lamps', for Smollett Ranelagh was nothing short of breathtaking. He was not alone. Like Vauxhall, Ranelagh drew a staggering array of 'People of Fashion', ranging from 'the Prince and Princess of Wales, accompanied by several Persons of Distinction' to Horace Walpole. Yet Ranelagh and Vauxhall evolved into very different spaces by the close of the eighteenth century. Ranelagh seemed to overtake Vauxhall as the most glamorous of the two, boasting an entrance fee of two shillings to Vauxhall's one in an attempt to attract a more genteel crowd. Vauxhall, meanwhile, became more associated with entertainment of the masses and more lewd pursuits. Despite such differences, both commercial pleasure gardens enjoyed considerable success as relatively serene escapes from the dirty, congested 'monster' that was London. Depending upon which of the 
commercial pleasure gardens one chose, he could 'see and be seen' among the most current company and fashions, or, just as easily, sneak off into a grotto with a lover. It seemed that everything was available at Vauxhall and Ranelagh, and Londoners could not get enough of it. ${ }^{36}$

Through a combination of personal and second-hand experience, midcentury colonists were very familiar with the charms of London's pleasure gardens. Although feeling oppressed by 'the heavy Air of the City' during his 1754-55 voyage to London, for instance, British American clergyman Edward Winslow 'was most agreeably surpis'd with the great Elegance of the Place \& Company' at the Vauxhall and Ranelagh Gardens. Writing to his son in 1760, the Annapolis gentleman Charles Carroll also recommended 'play houses, coffee houses, Renelaghs, Vuxhulls, Routs, Opera...must have allotted now \& then some hours to these Genteel \& necessary Amusements' ${ }^{37}$ Even as colonists like Winslow and Carroll celebrated the Vauxhall and Ranelagh Gardens, they knew that their local populations simply did not demand commercial pleasure gardens that matched London's in size or scope. Though the itinerant celebritypreacher George Whitefield's sermons drew crowds in the thousands, it would be hard to match such numbers with the lure of an orchestra or fireworks at a pleasure garden. Nor could purveyors of British American commercial pleasure gardens justify building a 150-foot diameter Rotunda as Ranelagh's owners had in 1742. But they could emulate these spaces as effectively as possible, laying down their own fine gravel paths which wound through an impressive array of squares, grottos, alcoves and vistas, constructing their own buildings intended for food, drink and entertainment, and putting on a string of spectacles. Urban colonists also, importantly, realized that they could use certain distinctive aspects of their surroundings - specifically British America's garden culture, urbanization, specimen exchange networks, demand for leisure spaces and rural identity - to move beyond sheer emulation and craft their own colonial versions of London's commercial pleasure gardens.

36 T. Smollett, The Miscellaneous Works of Tobias Smollett...In Six Volumes, ed. R. Anderson (Edinburgh, 1800), vol. VI, 97; Greig, "'All together and all distinct"', 64 (quote); Daily Advertiser, 23 May 1743; Westminster Journal or New Weekley Miscellany, 31 Aug. 1745; Porter, London: A Social History, 174-5. While other pleasure gardens existed in London specifically Cuper's Gardens, Marylebone Gardens, Mulberry Gardens, Dobney's Gardens and Bagnigge Wells - they all emulated Vauxhall and Ranelagh, and elites did not generally attend them. Greig, '“All together and all distinct"', 73 .

37 E. Winslow, 'Journal of an intended voyage on board the ship Early of Halifax, John Phillips, commander, from Boston to London, 16 Dec. 1754-30 Sep. 1755', Manuscripts and Archives Division, New York Public Library, 32, 45, 66, 63, 67; R. Hoffman, S.D. Mason and E.S. Darcy (eds.), Dear Papa, Dear Charley: The Peregrinations of a Revolutionary Aristocrat, as Told by Charles Carroll of Carrollton and his Father, Charles Carroll of Annapolis, with Sundry Observations on Bastardy, Child-Rearing, Romance, Matrimony, Commerce, Tobacco, Slavery, and the Politics of Revolutionary America (Chapel Hill, 2001), 166-74. 


\section{New York City's Vauxhall and Ranelagh Gardens}

By mid-century, urban swell made stand-alone commercial pleasure gardens more viable as colonists grew disenchanted with certain pitfalls of city life. Though leaders remained devoted to maintaining their cities' verdant identity and colonial cities generally remained greener and less congested than their Old World counterparts, such population growth had created new sanitation challenges in the colonies' largest cities. Unbathed bodies slogged through streets muddied by human and animal faeces, animals lay dead in the gutters and tanners and butchers dumped their noisome waste into thoroughfares and rivers. Such developments drove many urban dwellers to romanticize the supposedly 'healthy' aspects of the more 'natural' countryside in contrast to the enervating effects of their cities.

Residents of the two largest cities in America - New York City and Philadelphia - especially deemed their urban environs as unhealthy after mid-century. As colonists in South Carolina escaped the tropical fevers and suffocating humidity of the backcountry for the zephyrs of Charleston, their northern compatriots often found their cities overwhelming in the summer. Peggy Emlen swore during the summer of 1769 that she might be 'choaked with the dust' of Philadelphia if she did not soon escape to the countryside, while the New York City elite Cadwallader Colden somewhat angrily reminded the city's alderman 'to remove the Nusances' and drain 'the stagnating Waters' from their city's pestilent streets. ${ }^{38}$ Betsy Galloway, finally, was happy to hear that her mother had moved to Philadelphia merchant Robert Morris' country home in 1778, as she believed 'that part of the town is more healthy and pleasant than second street'. Genteel Philadelphians and New Yorkers like Emlen, Colden and Galloway increasingly fled their cities to enjoy 'the happy effects' of their rural surroundings. Yet the majority of colonists could not afford the monetary and temporal costs of such far-flung, exclusive pursuits, thus necessitating a new sort of urban public space which could satisfy both ordinary and wealthy colonists' desire for a convenient escape from urban life: this is where commercial pleasure gardens came in. ${ }^{39}$

Although in many ways natural outgrowths of nurseries, private gentlemen's gardens and urban commons/fields, British America's earliest commercial pleasure gardens - especially those in New York City - often emerged from pre-existing commercial, public spaces: specifically

38 S. Fatherly, Gentlewomen and Learned Ladies: Women and Elite Formation in Eighteenth-Century Philadelphia (Bethlehem, 2008), 119 (quote); C. Colden, The Letters and Papers of Cadwallader Colden, vol. III: 1743-47 (New York, 1918), 95.

39 Betsy Galloway to Grace Growden Galloway, 1778, Joseph Galloway Family Papers, 174383, Library of Congress, Washington, DC, box 1, folder 1; Scribner, "Happy effects of these waters"'; M.V. Melosi, The Sanitary City: Environmental Services in Urban America from Colonial Times to Present, abridged edn (Pittsburgh, 2008), ch. 1; J.A. Tarr, The Search for the Ultimate Sink: Urban Pollution in Historical Perspective (Akron, 1996); Reinberger and McLean, The Philadelphia Country House, 45. 
urban taverns and, occasionally, mineral spring spas. ${ }^{40}$ Ex-English Sergeant Thomas Scurlock, for example, conceived New York City's earliest commercial pleasure garden, 'Spring Garden', as a combination garden/tavern in 1740. Like purveyors of the famous Epsom Spa in England, Scurlock hoped to build on the alleged health of mineral waters to attract even more visitors. New York City's most popular commercial pleasure garden (eventually called 'Vauxhall' after London's famous venue), moreover, originated as a 'Mead House'. Though the Philadelphian Hannah Callender found that 'they have no gardens in or about New York which come up to ours of Philadelphia' while touring New York City in May 1758, she did enjoy visiting the mead house on the bank of the Hudson River where she found it 'customary to drink this liquor and eat cakes'. ${ }^{41}$ It is no surprise that commercial pleasure gardens emanated from popular spaces like spas and taverns. As genteel rural retreats so often associated with health and improvement, an urban mineral spring would be an ideal place to construct a commercial pleasure garden. Urban taverns - the most numerous and popular of all British American urban public spaces - were also natural venues for what might have otherwise been a risky business proposition on its own. ${ }^{42}$

Though other north-eastern cities like Philadelphia and Boston also harboured short-lived commercial pleasure gardens after mid-century which often stemmed from pre-existing taverns, the cities' religious leaders did everything in their power to stifle the multiplication of such supposedly lewd spaces. ${ }^{43}$ When a group of Philadelphians attempted to create a lottery to raise funds for public baths and pleasure grounds in the city in the 1760s, for instance, local clergy quickly stifled the attempt with a forceful - and effective - letter to their governor. One particularly religious mid-century Bostonian, similarly, considered 'the prodigious increase in licensed taverns and other Houses licensed to sell spirituous Liquors' as

${ }^{40}$ For other examples of commercial pleasure gardens originating from taverns, see W. Black, 'Journal of William Black, 1744', Pennsylvania Magazine of History and Biography, 1 (1877), 130; South Carolina Gazette, 5 Mar. 1744; Pennsylvania Mercury, 12 May 1737.

41 Garrett, 'A history of pleasure gardens', 66-70; New-York Gazette, 5 Feb. 1740; Callender, 'Extracts', 444-5.

42 D.W. Conroy, In Public Houses: Drink and the Revolution of Authority in Colonial Massachusetts (Chapel Hill, 1995), 243; Thompson, Rum Punch and Revolution; Carp, Rebels Rising; D. Shields, Civil Tongues and Polite Letters in British America (Chapel Hill, 1997); S.V. Salinger, Taverns and Drinking in Early America (Baltimore, 2002); Scribner, "'Quite a genteel and extreamly commodious house"'; Scribner, '“Happy effects of these waters"'; P. Hembry, The English Spa, 1560-1815: A Social History (London, 1990).

${ }^{43}$ For references to other commercial pleasure gardens, see Milroy, 'The politics of Penn's squares', 277; Sarudy, Gardens and Gardening, 129; G.A. Duclow, 'Philadelphia's early pleasure gardens', in Vallillo and Chach (eds.), 'Pleasure gardens', special issue, Performing Arts Resources; P.V. Fithian, Journal and Letters of Philip Vickers Fithian, ed. H.D. Farish (Charlottesville, 1983), 106; C. Blanchard, The Journal of Claude Blanchard, Commissary of the French Auxiliary Army Sent to the United States during the American Revolution, 17801783, trans. W. Duane, ed. T. Balch (Albany, 1876), 56; New England Weekly Journal, 16 Sep. 1740; New England Weekly Journal, 10 Feb. 1741; O.G. Sonneck, Early Concert-Life in America (1731-1800) (Leipzig, 1907), 20; Maryland Journal, 15 May 1776. 
providing 'the greatest Reason to fear will be attended with the most unhappy Consequences'. ${ }^{44}$ Much of these anxieties were directed toward class relations. Religious detractors in Boston and Philadelphia especially levelled their criticisms of 'open' public spaces like commercial pleasure gardens according to notions that such 'lewd' spaces would encourage disorder among the 'lower sorts'. Whether criticizing taverns as spaces where 'the poorer sort of People' would congregate and drink while 'their poor Families are suffering for want of Bread at Home', un-altered mineral springs as places where 'Horse-racing, cock-fighting, and boxing-matches, are standing amusements' or theatres as 'a Trap to draw in the modest and Innocent to a Love of Theatrical Entertainments', religious detractors in Boston and Philadelphia made life hard for any businessman who hoped to cultivate such 'open' public spaces. Thus, while a smattering of commercial pleasure gardens would ultimately sprout in Philadelphia and Boston, their roots were shallow and easily upturned by various cynics. New York City, meanwhile, embraced such leisure spaces. ${ }^{45}$

Such heightened religious opposition to public leisure spaces did not exist in New York City, thus allowing certain enterprising entrepreneurs commercial opportunities that their compatriots in Boston and Philadelphia found harder to enjoy. The colonist William Smith Jr called New York City 'one of the most social Places on the Continent' in 1757 while Lewis Hallam $\mathrm{Sr}$ - the head of the first professional British theatre company in North America - was happy to act in front of a 'very crowded assembly' in New York City in 1754. Hallam's Company hardly found such welcome in Philadelphia. After begging Pennsylvania's governor for permission to act in the Quaker city in 1754, Hallam was only allowed to enter Philadelphia after promising that his limited play run would contain 'nothing indecent or immoral' and that he would devote the profits of at least one of his performances to the poor of the city. The travelling actor was never even allowed in Boston. ${ }^{46}$ By attaching the earliest commercial pleasure gardens to pre-existing 'open' spas and taverns, New York City's businessmen minimized their financial risks while also providing demanding clientele yet another reason to visit their establishment. In quite simple terms, these men built upon an already booming public leisure sector. This is not to say that these proprietors did not face their fair share of difficulties - from financial hardship to seasonal variances to class conflict to revolution, New York City's commercial pleasure gardens would endure several challenges after 1765.

Between 1765 and 1776, New York City harboured the most numerous, highly developed, popular and well-documented commercial pleasure

44 Milory, Grid and the River, 36; Boston News-Letter, 10 Jul. 1750; Conroy, In Public Houses.

45 Boston Evening Post, 26 Jun. 1738; Marquis de Chastellux, Travels in North America, in the Years 1780, 1781, and 1782 (New York, 1827), 292-3; Pennsylvania Gazette, 19 Mar. 1754.

46 Smith, The History of the Province of New-York, 211; Pennsylvania Gazette, 15 Jan. 1754; Scribner, 'Transatlantic actors', 9. 
gardens of any north-eastern city: specifically, the 'Vauxhall' and 'Ranelagh' Gardens. In 1765, noted New York City tavern keeper Samuel Fraunces announced that his Vauxhall commercial pleasure would soon open: 'Being one of the pleasantest rural Retreats near this City is now opened for the Summer Season...[the] New Vaux Hall.' Fellow tavern keeper John Jones quickly followed suit, opening his own Ranelagh Garden in June 1765 where 'Ladies and Gentlemen' could find grand gardens, buildings and other fineries 'prepared for their Entertainment'. Though relatively short-lived when compared to their London namesakes, Fraunces' Vauxhall and Owens' Ranelagh seized upon New York City residents' rural desires, offering spaces within the confines of the city where colonists could relax in a more 'natural' - but still carefully manicured and civilized - setting. ${ }^{47}$

With entrance fees between one and three shillings (depending upon the event, place and marketing strategies) and vast grounds which required constant upkeep, New York City's commercial pleasure gardens welcomed colonists from a broad spectrum of urban life. Whether strolling, performing or ploughing, citizens of nearly every class and creed interacted with each other in the vibrant atmosphere of the pleasure garden. And locals were hardly the only patrons - travelling elites, acting troupes and performers also flocked to pleasure gardens as patrons and entertainers alike. Generally barred from enjoying the grounds, furthermore, black slaves and indentured servants laboured to cultivate gardens for free white customers. But purchasing a ticket hardly dissipated well-established notions of hierarchy. As historian Hannah Greig recently demonstrated in the context of London's commercial pleasure gardens, just because a diverse social company entered the same garden did not mean that they intermingled - on the contrary, in Greig's words such spaces 'expressed and underlined...status hierarchies'. With a larger number of ordinary and unfree labourers, a mass base of ordinary colonists with more money than ever, a growing upwardly mobile middle class and a self-conscious elite class, commercial pleasure gardens such as those in New York City would not only have followed - but perhaps even heightened - the London model. ${ }^{48}$

47 New-York Gazette, 16 May 1765; Garrett, 'A history of pleasure gardens', 82, 92, 106; NewYork Journal, 21 Jul. 1768.

${ }^{48}$ For entrance fees, see Sonneck, Early Concert-Life, 21-30; New-York Chronicle, 29 Jun. to 6 Jul. 1769; New-York Journal, 29 Jun. 1769. Greig, "'All together and all distinct"', 50-75. For an example of how such a social model of internal division extended into other public spaces (namely the tavern), see Scribner, "'Quite a genteel and extreamly commodious house"'. Philip Vickers Fithian noted slaves working in a gentleman's private pleasure garden in 1773, commenting 'after Mrs. Carter had given some orders to the Gardiners (for there are two Negroes, Gardiners by Trade, who are constantly when the Weather will any how permit, working in it) we walked out'. Fithian, Journal and Letters, 44. Not all gardeners, of course, were enslaved. When one man arrived in New York City in 1773, he advertised in the Rivington's New-York Gazetteer: 'A Gardiner, that is lately arrived from England, who understands that business in all its branches, as kitchen, flower, and pleasure garden, 
Geography proved vital for Ranelagh and Vauxhall's success. Importantly, both commercial pleasure gardens were set on the edge of the city, close enough to be easily accessible but far enough away to retain a somewhat rural character. Ranelagh and Vauxhall were only one quarter of a mile from St Paul's Cathedral and three-quarters of a mile from the bowling green at the southern tip of Manhattan Island. Those urbanites not wealthy enough to purchase or rent a chaise could easily walk to the gardens, while more elite patrons could enjoy a short ride to the gardens. For perspective, a man could attend service at Trinity Church in the morning followed by a drink at the nearby Burns Coffee House (just south of the church by the bowling green) in the afternoon and finish his day with an evening's stroll at Vauxhall or Ranelagh, all with only about a mile of total walking. As the owner of Vauxhall asserted in 1774, the gardens were 'so contiguous to the city that a moderate walker may, in 15 or 20 minutes, be in any part' of New York City. 'No place', in his estimation, was 'better calculated for the reception and genteel accommodation of single gentlemen, or gentlemen with their families' than his commercial pleasure garden. ${ }^{49}$

The benefits of Ranelagh's and Vauxhall's location extended beyond distance and accessibility. As demonstrated by Figure 6, the commercial pleasure gardens were situated on raised bluffs, which not only would have made them more accessible to cooling zephyrs, but would have also provided a clear view of the Hudson River. Like Londoners who had easy access to the Thames River from their own Vauxhall commercial pleasure garden, customers of New York City's Vauxhall and Ranelagh commercial pleasure gardens could look out over the North River and enjoy 'a full prospect of the shipping, as low as the narrows, and a view for many miles up the river; with a very pleasing and extensive prospect of the Jersies, Staten-Island, etc.'. Figure 6 also shows a series of garden-like spaces stretching south from Vauxhall towards Ranelagh, indicating that the commercial pleasure gardens were perhaps visually linked. Ultimately, these gardens were products of their surrounding environment as much as the world within their walls. ${ }^{50}$

The owners of New York City's commercial pleasure gardens strove to create a controlled environment where a diverse company could enjoy the benefits of the natural world. When Erasmus Williams purchased New York City's Vauxhall commercial pleasure garden in summer 1774, he especially advertised the garden's healthful nature. The purveyor proudly announced 'from its lively, healthy and agreeable situation on the banks of the North-River', the pleasure garden was 'extremely healthy from its

grafting and budding of fruit trees, in the most approved method, is welling to engage with any gentleman, either in this or any of the neighboring provinces, as a Gardiner, or Overseer of an estate.' Rivington's New-York Gazetteer, 13 May 1773.

${ }^{49}$ New-York Gazette; and the Weekly Mercury, 6 Jun. 1774.

${ }^{50}$ New-York Gazette; and the Weekly Mercury, 6 Jun. 1774. 


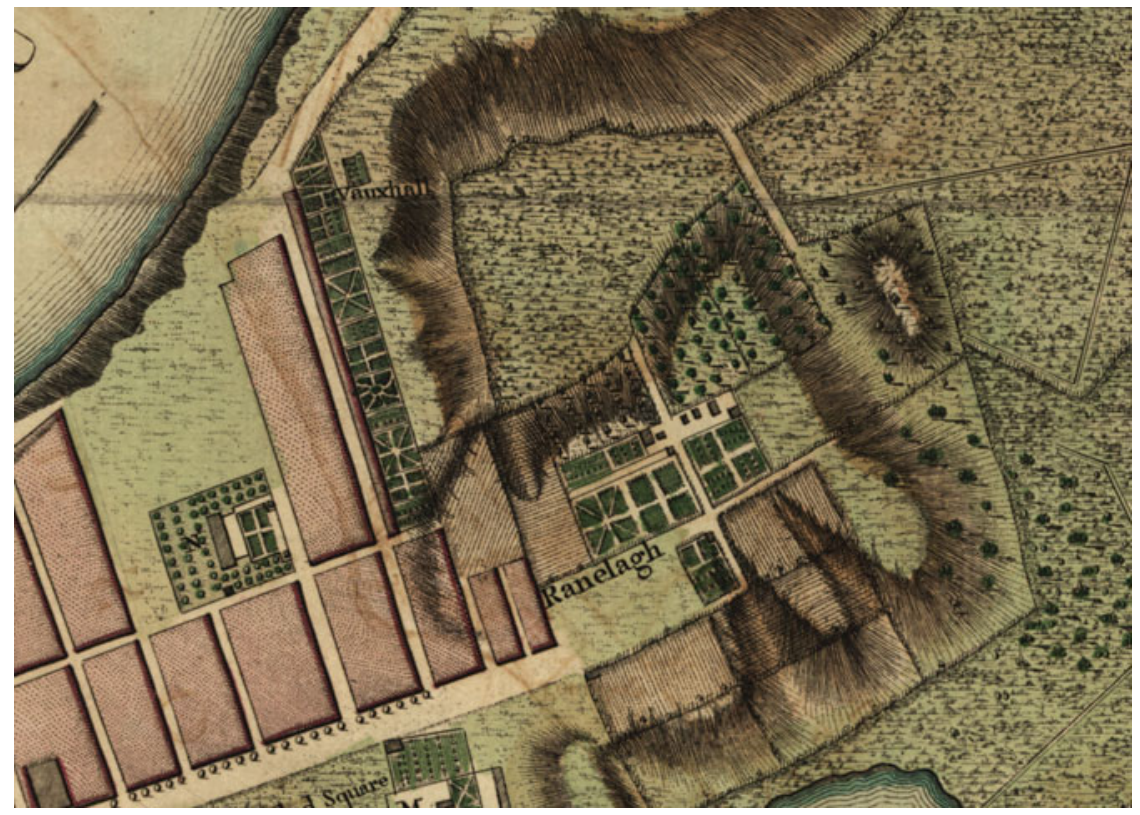

Figure 6: (Colour online) 'Detail depicting New York City's Vauxhall and Ranelagh pleasure gardens', from A Plan of the City and Environs of New York in North America (London, 1776), map, retrieved from the Library of Congress, www.loc.gov/item/2002623929 (accessed 14 Jun. 2016).

eminence and dryness of soil, with the most acceptable sea-breezes in the heat of the summer' ${ }^{51}$ Urbanites would have been especially receptive to such professions of health, as during the summer their cities often became hot, stinky, humid nests of disease. Many New Yorkers surely harboured the notions of one of their fellow Britons, who asserted in the early 1770s 'no one will pretend to deny that a Country Air is generally, if not always, more wholesome than the condensed Air of Towns'. The idea of retreating to a clean garden with cool breezes to dry one's brow must have drawn a fair number of health-seeking customers. ${ }^{52}$

Plants, of course, were key to such efforts. Luckily for purveyors of commercial pleasure gardens, North America had no shortage of exotic flora. During the eighteenth century, resident gentlemen scientists such as William Byrd II, and Philadelphia's professional plant hunters John and

${ }^{51}$ New-York Gazette; and the Weekly Mercury, 6 Jun. 1774.

52 Virginia Gazette, 14 Oct. 1773. For further discussion of early English ideologies of air and health, see M. Jenner, 'The politics of London air: John Evelyn's Fumifugium and the Restoration', Historical Journal, 38 (1995), 535-51; Milroy, 'The politics of Penn's squares', 275; Scribner, "'Happy effects of these waters"', 409. 
William Bartram as well as visitors Mark Catesby and Swede Peter Kalm, gathered numerous new botanical specimens. British North America's well-established position in larger webs of global exchange only bolstered the colonies' already impressive array of plants. Colonial gentlemen interacted in the 'republic of letters' to swap plant specimens and seeds with comrades throughout the world, while shopkeepers worked hard to import the most popular plants from England, which were themselves often sourced from far-flung locations. By the second half of the eighteenth century, owners of British American commercial pleasure gardens would have had a staggering variety of plants to choose from. ${ }^{53}$

Unfortunately, little historical evidence remains detailing specific plants that graced New York City's commercial pleasure gardens. The city view of New York City from 1767 (Figures 1 and 2) delineates New York City's Ranelagh Garden with highly detailed trees, shrubs and squared-off plots, while an image from 1776 provides a less-detailed illustration of both Vauxhall and Ranelagh (see Figure 6). Of course, one must approach such maps with caution, as it is quite possible that the artist simply drew what he considered a 'typical' garden for the time rather than what was actually there. By the mid-eighteenth century, the Palladian movement of architecture and landscaping had led many British gardeners to transform their manicured landscape 'from a formal one dominated by straight lines into an asymmetrical, "natural" foil for the measured, formal, and balanced buildings' often paired with the gardens. Compared with such developments, the above images seem to depict rather old-fashioned gardens defined by order rather than the 'wilderness' that gardeners increasingly attempted to introduce into their carefully cultivated plots. Note Rocque's 1746 image of London's Vauxhall commercial pleasure garden (Figure 5): scattered trees dominate the landscape as much as orderly walkways. When not strolling down one of the main thoroughfares, visitors would have meandered through the winding paths that the garden's owners cleared in order to create a 'natural aesthetic. ${ }^{54}$

This is where further records become so valuable. Not only emulating London's pleasure gardens in name, colonial commercial pleasure gardens like New York City's Vauxhall and Ranelagh also followed their London predecessors in offering customers 'several noble vistas of very tall trees, where the spaces between are filled up with very neat hedges; and

${ }^{53}$ K.S. Murphy, 'Collecting slave traders: James Petiver, natural history, and the British slave trade', William and Mary Quarterly, 70 (2013), 637-70; S.S. Parrish, American Curiosity: Cultures of Natural History in the Colonial British Atlantic World (Chapel Hill, 2006); E.C. Nelson and D.J. Elliott (eds.), The Curious Mister Catesby: A 'Truly Ingenious' Naturalist Explores New Worlds (Athens, GA, 2015); P. Kalm, Peter Kalm's Travels in North America: The English Version of 1770, ed. A.B. Benson (New York, 1937); W. Darlington, Memorials of John Bartram and Humphry Marshall (Philadelphia, 1849); F. Knobloch, 'Flora', in Sackman (ed.), A Companion to American Environmental History, 327-44; J. O'Neill and E. McLean, Peter Collinson and the Eighteenth-Century Natural History Exchange (Philadelphia, 2008).

${ }^{54}$ Reinberger and McLean, The Philadelphia Country House, 31; O'Malley, Keywords, 669. 
within are planted variety of flowers and sweet smelling shrubs'. Samuel Fraunces' records point to such efforts. When Fraunces sold the gardens in January 1771, for example, he explained that the grounds had ' 36 lots and a half of ground laid out to great advantage in a pleasure and kitchen garden well stocked with fruit and other trees, vegetables, \& $c^{\prime}$. Though not delineating individual flora species, Fraunces nevertheless alluded to a variety of plants, trees and shrubs in his Vauxhall pleasure garden. The nearby fresh water pond (about 200 yards east of the gardens) would have also been helpful in providing a constant source of water for especially stubborn or foreign plants. While strolling through Vauxhall or Ranelagh Gardens, New Yorkers would have most likely been greeted by a more diverse array of local and foreign (manicured) plants, trees and flowers than many of them had ever seen in one place. A far cry from the crowded, mucky nature of city streets, these verdant promenades would have struck many urban colonists as pristine retreats of natural splendour. ${ }^{55}$

Yet, perhaps even more importantly, owners of commercial pleasure gardens had created spaces that could compete visually and ideologically with gentlemen's private gardens. Take New York City gentleman merchant Nicholas Bayard's country house gardens just to the east of Ranelagh, for example. ${ }^{56}$ By mid-century, colonial gentlemen like Bayard had transformed their rural private gardens into more English-style spaces, featuring a dizzying array of local and exotic plants, pristine landscaping and buildings such as pavilions, bath houses, spring houses, greenhouses and ornate bridges. Bayard kept 16 separate plots of gardens, accentuated by walkways, trees, shrubs and outbuildings. His own gardens, in fact, mirrored those of nearby Vauxhall and Ranelagh. Yet regular citizens could not visit Bayard's genteel estate. Tickets did not gain one access to such private grounds. Commercial pleasure gardens, however, offered a vast array of urban colonists the chance to stroll similar grounds. Here, they could enjoy 'Plants and Fruits of...every Clime and Kind' like those in the gardens of Bayard and perhaps reflect upon 'excellent assortments of flower and garden curiosities'. Commercial pleasure gardens, in short, extended gentlemen's private gardens - both ideologically and physically - to a larger swathe of the urban populace. ${ }^{57}$

55 Garrett, 'A history of pleasure gardens', 67; J. Montresor, Plan de New-York et des environs, 1775 (Paris, 1777); W. Harrison, New and Universal History, Description and Survey of the Cities of London and Westminster, the Borough of Southwark (London, 1775), 512; P. Borsay, 'Pleasure gardens and urban culture in the long eighteenth century', in J. Conlin (ed.), The Pleasure Garden, from Vauxhall to Coney Island (Philadelphia, 2013), 58; New-York Gazette, 14 Jan. 1771.

56 Nicholas Bayard was a notable merchant of New York City. He brokered numerous land deals at mid-century, and owned various servants. See, for instance, New-York Mercury, 3 Mar., 2 Jun., 16 Jun. 1755. He was also unhappy when miscreants destroyed some of his locust trees 'planted along-side of the lane aback of my woods, as an ornament and conveniency for gentlemen, and others, who take their walks that way'. New-York Gazette, or Weekly Post-Boy, 11 Sep. 1758. Apparently, by 1762 the destruction of his farm by miscreants had grown even worse. See New-York Gazette, or Weekly Post-Boy, 17 May 1762.

57 Bridenbaugh, Cities in Revolt, 340 (quote); Pennsylvania Gazette, 26 Jul. 1770; C. Cagnato, G.J. Fritz and S.L. Dawdy, 'Strolling through Madame Mandeville's garden: the real 
New York City's commercial pleasure gardens offered customers more than 'a little romantic rural scene'. In fact, some of their biggest draws were the various exhibits, performances and oddities that purveyors advertised. If the opportunity to stroll through botanical lanes brought colonists to commercial pleasure gardens, many owners must have thought, a spate of new attractions would keep them coming back, and perhaps with friends. It worked on captain of the Royal Navy, William Owen. Shortly after arriving in New York City in July 1768, Owen 'made a party to Renelagh Gardens' where there was a bear 'chained to a ring near the house'. Thinking the creature 'uncommonly docile and tractable', Owen 'took the liberty of taking [the bear] by the ears, which he instantaneously resented by making a snatch and bite at my right leg'. While Owen was lucky enough to escape with a torn stocking, some minor scratches and the mockery of his companions, the captain noted that a few days later the Ranelagh bear killed 'a Black Boy... and was the next minute shot through the head'. Though on the surface a rather sad event off-handedly reported by Owen, the case of the Ranelagh bear provides an important example of how visitors to commercial pleasure gardens felt safer than they might have otherwise when interacting with a creature considered symbolic of the dangers of the 'wilderness'. It is highly unlikely that Owen would have attempted to take a bear 'by the ears' if he came across it in the woods. But this was different. Owen and his comrades felt as if because they were surrounded by well-manicured gardens in a contrived environment, the wild animal that was chained up to the punch house might also be as equally 'docile and tractable'. They quickly found otherwise. ${ }^{58}$

While most attractions at Vauxhall and Ranelagh were not so hazardous, they remained devoted to making colonists feel comfortable - even excited - in such a hybrid environment. New York City's commercial pleasure gardens were especially known for their firework shows between 1767 and 1769. As dazzling displays of pyro-wonder, the fireworks alone would have impressed onlookers as they lit up the night sky, turning the surrounding gardens into illuminated other worlds. The shrubs, flowers and trees that provided shade and colour during the day would have been transformed by the bursts of light into mysterious formations and eerie shadows. Firework shows, in short, added yet another dimension to colonists' fascination with the wonders of the natural world. Yet owners did not stop there, as the fireworks themselves often depicted objects of the

and imagined landscape of eighteenth-century New Orleans, Louisiana', Journal of Ethnobiology, 35 (2015), 235-61; J.H. Ernstein, 'Constructing context: historical archaeology and the pleasure garden in Prince George's county, Maryland, 1740-1790', Boston University Ph.D. thesis, 2004. While visiting George Whitefield's Georgia orphan house in 1746 , one colonist remarked that the grounds boasted a 'Garden, which is a very extensive one, and well kept up, is one of the best I ever saw in America, and you may discover in it Plants and Fruits of Almost every Clime and Kind'. Pennsylvania Journal, 9 Dec. 1746.

58 Callender, 'Extracts', 448; W. Owen, Narrative of American Voyages and Travels of Captain William Owen, R.N., and Settlement of the Island of Campobello in the Bay of Fundy, 1766-1771, ed. V.H. Paltsits (New York, 1942), 26. 
natural world as they burst overhead. In July 1768, the Ranelagh Garden hosted 'a grand Set of Fire-Works, Divided into Five Acts', featuring displays that resembled 'a Flower-Pot', 'a beautiful Palm Tree, with a Tornent [sic] of Brilliant Fire' and 'a Cistern of Water going out and coming in twelve Times'. Fraunces similarly announced the firing of 'a magnificent Set of Fire-Works' at Vauxhall Garden in October 1769. Like the Ranelagh display, Vauxhall's night show featured fireworks that recreated (among other things) 'a beautiful Garland of Flowers' and 'a beautiful [Yew]Tree illuminated with Green Fires, and adorned with Diamonds, Chinese Fountains, and brilliant Fire on each Side'. Just as Fraunces and Jones utilized fireworks to transform their grounds into even more dynamic spaces, so too did they attempt to recreate their gardens in the sky. The natural world was both illuminated around onlookers and bursting into light above them. It must have been quite the thrill..$^{59}$

Like Owen's run-in with the Ranelagh bear, however, such shows were not without their hazards. In his July 1768 advertisement for a firework show at the Ranelagh Garden, Mr Jones 'humbly requested that no Persons will throw Squibs [small exploding fireworks] in the garden, at least, before the Fire-Works are over'. 'Besides the Terror [squibs] put the Ladies in', Jones explained, 'the Evening's Entertainment might be entirely spoiled by an Accident happening to one of the Pieces.' Apparently, just such an accident had happened during a previous display, forcing the show to end early. This was not good for business, and Jones had to make sure that from now on 'ever Thing will be conducted with the utmost Regularity and Decorum'. If one were to transform the natural world into a garden of safety and health, he hardly needed squibs exploding around customers and firework shows exploding on the ground, which would only bring commercial pleasure gardens down to the level of an uncivil common. Since colonial urbanites lived in constant fear of fires, moreover, they would have deemed such accidents absolutely unacceptable. Paying customers hardly expected fires and 'terror' in the bucolic confines of the commercial pleasure garden. ${ }^{60}$

On the contrary, New Yorkers expected an experience of genteel entertainment in their commercial pleasure gardens. From wax-works 'representing the Queen of Sheba bringing presents to King Solomon, with a view of his Palace, Court Yard, and Gardens' to 'Concert[s] of Vocal and Instrumental Music', New York City's commercial pleasure gardens offered patrons an array of diversions. Such amusements helped to lure colonists away from other leisure spaces like taverns and playhouses because commercial pleasure gardens offered all the same services in one beautiful location. A visitor could stroll through Vauxhall's or Ranelagh's well-manicured gardens instead of jostling for a seat at the General Wolfe

${ }^{59}$ New-York Journal; or, the General Advertiser, 21 Jul. 1768; New York Chronicle, 28 Sep. to 5 Oct. 1769.

${ }^{60}$ New-York Journal; or, the General Advertiser, 21 Jul. 1768; New-York Gazette, 4 Jul. 1768. 
Tavern or the Merchant Coffee House. He or she could also find a pleasant grove of spring flowers to lounge among while watching a play rather than crowd into a packed playhouse so often defined by 'Riotous Scene[s]' and uncivil behaviour. Fraunces and Jones knew their competition all too well - both men, after all, also owned taverns - and thus understood the sort of measures necessary to lure the most customers as possible. Ultimately, their gardens remained the main attraction. Other diversions only added to the inherent charm of these rural paradises. ${ }^{61}$

\section{Revolution comes to Vauxhall and Ranelagh}

Though British American commercial pleasure gardens blossomed between 1765 and 1775, these important public spaces could not avoid the relative disorder of the years that historians now so commonly refer to as a time of 'pre-revolutionary tumult'. ${ }^{62}$ Colonists' ability to utilize public spaces to demonstrate their growing disregard for the authority of local leaders has been well documented by historians. ${ }^{63}$ So too have other scholars asserted that London's commercial pleasure gardens served as central spaces where colonists debated issues of class and social difference. ${ }^{64}$ By 1765 , however, the disorder of the imperial crisis had real effects on urbanites' comprehension of their rural-urban existence and, in turn, steadily disintegrated commercial pleasure gardens. As many New Yorkers grew weary of imperial mandates, they increasingly connected certain elite men - and their genteel homes and gardens - with imperial oppression.

On 1 November 1765, for instance, hundreds of angry colonists stormed through New York City to protest the recently instituted Stamp Act. The mob convened in a variety of public spaces before burning Governor Cadwallader Colden's gilded coach and various effigies in front of Fort George. Yet, as a New-York Mercury article made clear, 'the business of the night [was not] yet...concluded'. Energized from their success, the rioters marched one mile north to Major Thomas James' recently refurbished home, 'Vaux-Hall'. While Samuel Fraunces had purchased the plot only months earlier with the intention of developing it into a

61 New-York Gazette, 2 Apr. 1770; New-York Chronicle, 29 Jun. to 6 Jul. 1769; Sonneck, Early Concert-Life, 166-70; New England Weekly Journal, 16 Sep. 1740; New-York Gazette, 11 Feb. 1765; New-York Mercury, 28 Dec. 1761; New-York Gazette, 7 Dec. to 14 Dec. 1767.

62 For 'pre-Revolutionary tumult', see G.R.G. Hodges, 'The laboring republic', in E.G. Gray and J. Kamensky (eds.), The Oxford Handbook of the American Revolution (Oxford, 2013), 580.

63 Thompson, Rum Punch and Revolution; Carp, Rebels Rising; Conroy, In Public Houses; Bridenbaugh, Cities in Revolt; Nash, Urban Crucible; P. Maier, From Resistance to Revolution: Colonial Radicals and the Development of American Opposition to Britain, 1765-1776 (New York, 1972).

64 Greig contended that London's Vauxhall and Ranelagh were spaces where urbanites more clearly defined differences in status, while Nosan argued that these gardens diminished status gaps. Greig, "“All together and all distinct"'; G. Nosan, 'Pavilions, power and patriotism: garden architecture at Vauxhall', in M. Conan (ed.), Bourgeois and Aristocratic Cultural Encounters in Garden Art, 1550-1850 (Washington, DC, 2002), 101-21. 
commercial pleasure garden, he had recently relocated to Philadelphia and had subletted the grounds and home to James for three years. With rumours abounding that James had previously declared he would 'cram the stamp down [colonists'] throats with the point of my sword', the major made a perfect target for the incensed mob - they burned down his home and much of the surrounding gardens. ${ }^{65}$ With shrubs, topiaries and outbuildings in flames, flower beds trampled and an incensed mob running amuck through New York City's various public spaces, the city's dual urban-rural existence must have felt less plausible than ever before. ${ }^{66}$

The relative disorder of the late 1760s and early 1770 s ultimately took its toll on Vauxhall and Ranelagh. Though Fraunces opened his commercial pleasure garden in 1768 after repairing the extensive damage of the Stamp Act riots (James's burned-over gardens and house would have been ideal for renovation, and some of the plants may well have benefited from the fire), by 1771 he decided to sell the Vauxhall commercial pleasure garden. While the tumult of the imperial crisis surely affected Fraunces' decision to sell, he was sure to note that it was 'for no other reason whatever than the proprietor not being able to attend both his houses in the manner he could wish'. Historian Thomas Garrett has also contended that Fraunces realized that the city's regulation efforts were about to necessitate extreme landscaping at Vauxhall that would render its environs far less rural and beautiful than they had been. Fraunces simply got out while he could, and by October 1773 sold the land to the dry goods merchant Erasmus Williams who kept the business running until $1776 .{ }^{67}$ Jones, meanwhile, was also experiencing difficulties: his Ranelagh Garden sputtered out of business by March 1769 (probably due to a combination of financial and health issues that plagued Jones) and was parcelled up and auctioned off. One portion of the grounds, interestingly, was sold to eventually harbour the New York City's hospital. Unfortunately, the hospital burned down on 28 February 1775 before it was 'quite finished'. In retrospect, it was somewhat fortuitous that Jones and Fraunces sold their commercial pleasure gardens before 1775 , for their city - and the grounds upon which their commercial pleasure gardens had once stood - were about to be consumed by all-out war. $^{68}$

After the first shots of the Revolutionary War were fired in April 1775, New York City and its surrounding environs rather quickly devolved into

${ }^{65}$ For 'pre-Revolutionary tumult', see Hodges, 'The laboring republic', 580; New-York Mercury, 7 Nov. 1765; J. Lemisch, Jack Tar vs. John Bull: The Role of New York's Seamen in Precipitating the Revolution (New York, 1997), 81; Garrett, 'A history of pleasure gardens', 79. According to the New-York Mercury, 27 Jun. 1758, 'the House of Mr. Keen (commonly called Vaux Hall)' existed. It is very likely that this is the site that Fraunces purchased in 1765 and subletted to James.

${ }^{66}$ New-York Gazette, 4 Jul. 1768.

${ }^{67}$ New-York Gazette, and the Weekly Mercury, 14 Jan. 1771; Garrett, 'A history of pleasure gardens', 88-9.

68 Garrett, 'A history of pleasure gardens', 119; [E. Schaukirk], 'Occupation of New York city by the British', Pennsylvania Magazine of History and Biography, 10 (1887), 418. 
a garrisoned battlefield. American troops entered New York City in March 1776 and quickly went about turning the city into a garrisoned warzone. Shortly thereafter, one New York City resident found that his city had been transformed into 'a city of war'. He was quite right. In September 1776, continental forces had burned much of New York City to the ground as they escaped invading British troops. Almost 1,000 homes were reduced to ashes, along with the city's once-dominant Trinity Church. British forces would occupy New York City until the end of the war in $1783 .{ }^{69}$

The British military presence combined with the destruction of the city and an influx of fleeing loyalists and continental prisoners of war had real effects on New York City. Visitors to the city during the Revolution remarked upon the city's stenches, crowding and diseased environment more than ever before. When the Englishman Nicholas Cresswell arrived in New York City in June 1777, he was disgusted to find colonists, diseased with 'the Itch, Pox, Fever, or Flux', trudging through 'noisome vapours' and 'unwholesome smells' occasioned by the influx of citizens and troops into the ashen, diseased city. Such wartime conditions necessitated a change for the Vauxhall commercial pleasure garden - recognizing the garden's ready-made environment, British officials took Vauxhall away from poor Erasmus Williams and turned it into a military hospital. A Hessian soldier stationed in New York City named Johnann Conrad Döhla often visited injured friends who were kept in Vauxhall, and duly noted in his personal diary whenever a comrade 'died...in the hospital called Vauxhall in New York'. Though no longer hosting entertainments such as firework and wax shows, the Vauxhall grounds continued to serve as a key venue for those seeking health. ${ }^{70}$

By August 1779, New York City's elite 'gentlemen and ladies' demanded at least a taste of their previous commercial pleasure garden culture in their burned-out city, and consequently 'railed in and painted green...the walk by the ruins of Trinity Church and its grave-yard'. A Moravian priest living in New York City at the time noted, 'benches placed there and many lamps fixed in the trees, for gentlemen and ladies to walk and sit there in the evening. A band plays while the commander is present, and a sentry is placed there, that none of the common people may intrude.' By 1779, elite New Yorkers had apparently joined their brethren in Boston and Philadelphia in their belief that they could not have a truly 'healthy' garden

69 'Garish Harsin to William Radclift, 13 Feb. 1776', in Mercantile Library Association, New York City during the American Revolution (New York, 1861), 87; J.L. Van Buskirk, Generous Enemies: Patriots and Loyalists in Revolutionary New York (Philadelphia, 2002), Introduction.

70 N. Cresswell, The Journal of Nicholas Cresswell, 1774-1777 (London, 1925), 244; Döhla, A Hessian Diary of the American Revolution, 44, 56, 123, 138, 145, 228, 231. Colonial mineral spring spas such as Pennsylvania's Yellow Spring Spa were also converted into hospitals during the American Revolution. J.L. Cotter, D.G. Roberts and M. Parrington, The Buried Past: An Archaeological History of Philadelphia (Philadelphia, 1992), 404; J.S. Futhey and G. Cope, History of Chester County, Pennsylvania, with Genealogical and Biographical Sketches (Philadelphia, 1881), 101. 
environment if their social inferiors were present. They had watched on as the 'rabble' had burned Vauxhall to the ground 14 years earlier, and had witnessed ordinary colonists revel as New York City burned around them in September 1776. Such activities had surely influenced New York City's 'gentlemen and ladies' in their decision to place a 'sentry' at the garden's entrance so 'that none of the common people could intrude' on their otherwise controlled and genteel Trinity Church garden. By 1779, elites had - at least temporarily - returned New York City's commercial pleasure gardens to their exclusive roots. Unable to cultivate private pleasure gardens in and around the decimated environs of New York City, these self-conscious elites had to make do with shared pleasure grounds. ${ }^{71}$

Demonstrating the growing class struggles in Revolutionary America, many New Yorkers found such a show of exclusivity and leisure abhorrent during a period of war. At the same time that so many 'honest people' could not procure food and shelter, the city's elites had pompously adapted 'a house opposite [the Trinity pleasure garden] to accommodate the ladies or officer's women'. A local loyalist teenager damned the site in a poem, hoping that thunder and lightning might wipe it out, while countless others watched from beyond the sentry's post, wondering how such trifles could be pursued in an atmosphere of want and death. The majority of New York City ordinary residents, in short, deemed the commercial pleasure garden a superfluous relic of peace. Their city was a shadow of its former self, rather detached from the countryside and marred by disease, filth and hunger. Their desire for an urban-rural existence would have to be put on hold, at least until the conclusion of the war. $^{72}$

Like their intertwined urban centres, British American commercial pleasure gardens evolved (and, in some cases, devolved) with the ebbs and flows of a global war. Yet the Revolutionary War - at least in the context of American commercial pleasure gardens - should be considered a brief blip in the otherwise steady evolution of British American urbanites' efforts to harness the advantages of their rural surroundings. Culminations of numerous mid-eighteenth-century British American impetuses - specifically garden culture, urbanization, specimen exchange networks, demand for leisure spaces and a distinct rural identity - commercial pleasure gardens emerged as some of the most important public spaces for understanding how colonists attempted to craft their urban centres into 'cities in the wilderness' and, in turn, take advantage of their supposedly 'natural', 'healthy' surroundings. Colonists' federal successors would continue their efforts in earnest, rebuilding commercial pleasure gardens from New York City to Charleston, opening their gates to a broad collection of visitors, and further blurring the lines of civilization and wilderness, urban and rural in their quest to realize a new nation.

71 [Schaukirk], 'Occupation of New York city by the British', 427, 429-30.

72 Van Buskirk, Generous Enemies, 34-5. 